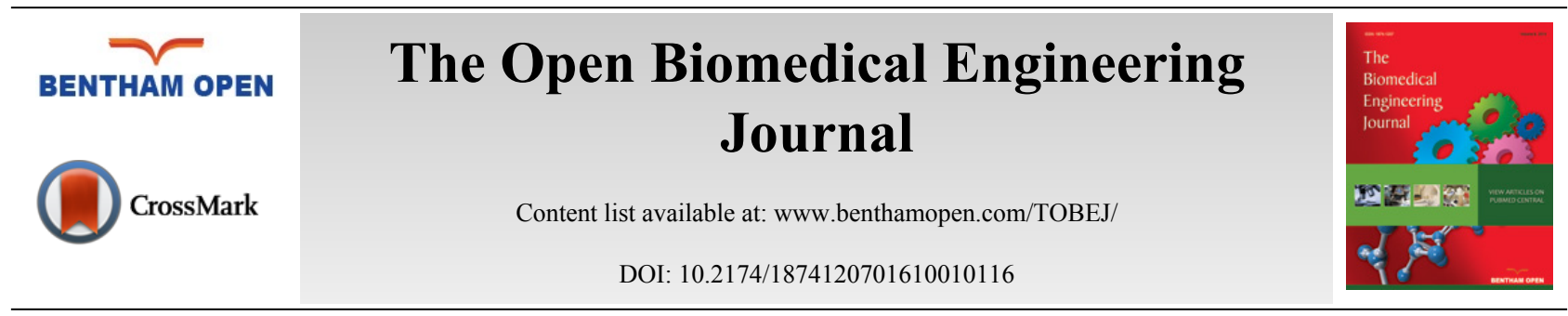

\title{
RETRACTION
}

\section{Retraction Notice: Isolation and Characterization of an Aeromonas punctata Bacteriophage}

Cheng Kai ${ }^{1,2}$, Zhang Denglan ${ }^{1}$, Deng Jingxuan ${ }^{2}$ and Zhao Yijun ${ }^{1, *}$

${ }^{I}$ Key Laboratory of Ecological Remedlation of Lakes and Rivers and Algal Utilization of Hubei Province, College of Resources and Environmental Engineering, Hubei University of Technology, Wuhan, Hubei, 430068, P.R. China

${ }^{2}$ College of Life Science, Central China Normal University, Wuhan, Hubei, 430079, P.R. China

\section{RETRACTION}

The Publisher and Editor have retracted this article [1] in accordance with good ethical practices. After a thorough investigations we believe that the peer review process was compromised. The article was published on-line on 31-08-2015.

\section{REFERENCES}

[1] C. Kai, Z. Denglan, D. Jingxuan, and Z. Yijun, "Isolation and Characterization of an Aeromonas punctata Bacteriophage", Open Biomed. Eng. J., vol. 9, pp. 185-187, 2015.

(C) Kai et al.; Licensee Bentham Open.

This is an open access article licensed under the terms of the Creative Commons Attribution-Non-Commercial 4.0 International Public License (CC BY-NC 4.0) (https://creativecommons.org/licenses/by-nc/4.0/legalcode), which permits unrestricted, non-commercial use, distribution and reproduction in any medium, provided the work is properly cited.

\footnotetext{
* Address correspondence to this author at the College of Resources and Environmental Engineering, Hubei University of Technology, Hubei, 430068, P.R. China; E-mail: 1829088302@qq.com
} 